\title{
Dynamics of Major Cereals Productivity in Nepal
}

\author{
Samaya Gairhe ${ }^{1 @}$, Hari Krishna Shrestha ${ }^{2}$ and KrishnaTimsina ${ }^{3}$ \\ ${ }^{1}$ Nepal Agricultural Research Council, Singhadurbar Plaza, Kathmandu; @: samaya43@gmail.com \\ iD https://orcid.org/0000-0002-1735-3334 \\ ${ }^{2}$ National Citrus Research Program, Pripattle, Dhankuta; <hkshrestha_1@yahoo.com> \\ ${ }^{3}$ Socioeconomics and Agricultural Research Policy Division, Khumaltar; <krishnatimsina2000@gmail.com>
}

Received 12 Nov 2017, Revised 7 Jan 2018, Accepted 25 Feb 2018, Published 28 April 2018

Scientific Editors: Tek Bahadur Gurung, Yuga Nath Ghimire, Jiban Shrestha Copyright (C) 2018 NARC. Permits unrestricted use, distribution and reproduction in any medium provided the original work is properly cited.

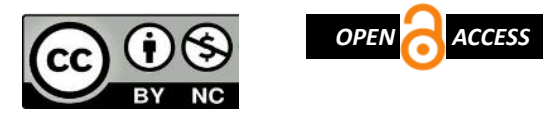

Licensed under the Creative Commons AttributionNonCommercial 4.0 International (CC BY-NC 4.0)

\begin{abstract}
Cereal crops have played major roles in addressing food security issues in Nepal. In recent years there have been fluctuations in crop production and demands situations due to various reasons. Thus, the present study aims to analyze the dynamics of major cereals productivity in Nepal from 1995 to 2014. Focus group discussions were done in mid-hills and tarai of Nepal in 2015. Percentage change, compound growth rate, annual rate of change, coefficient of variation, instability index were calculated to analyze results. The result shows that the area, production and productivity of major cereals had an increasing trend over the study period. The major factors contributing on productivity increase in cereal crops were irrigation facilities, use of improved and hybrid seeds, chemical fertilizer and better technical knowhow among the farmers. For effective adoption of research outputs to improve the productivity emphasis should also be given on promotion of public private partnership (PPP) in research and development.
\end{abstract}

Keywords: Cereals, Food security, Policy intervention, Trend of cereals productivity

सारंश

नेपालको खाद्य सुरक्षाको चुनौतीलाई समाधान गर्न अन्नबालीको महत्वपूर्ण भूमिका रहि आएको छ। हालका बर्षहरुमा बालीको उत्पादन, उत्पादकत्व तथा खपतमा असन्तुलन भएको पाईन्छ। तसर्थ, नेपालमा लगाइने मुख्य अन्नबालीहरुको उत्पादकत्वमा ई.सं. १९९५ देखि २०१४ सम्म भएका उतार चढावको विश्लेषण गर्ने उद्देश्यले यो अध्ययन गरिएको हो। साथै समूह केन्द्रित छलफल मध्य पहाड तथा तराईमा २०१५ मा गरिएको थियो । परिवर्तन प्रतिशत (Percentage change), मिश्रित बृद्धि दर (Compound growth rate), वार्षिक बृद्धि दर (Annual growth rate), गुणांक विविधता (Coefficient of variation),अस्थिरता सूचकांक (Instability index) हरु प्रयोग गरी नतिजा विश्लेषण गरिएको थियो । नतिजानुसार समग्रमा मुख्य अन्नबालीहरुको क्षेत्रफल, उत्पादन तथा उत्पादकत्वहरुको बढ़दो प्रवृत्ति देखियो । उत्पादकत्व बृद्धिको मुख्य-मुख्य कारक तत्वहरुमा किसानहरुमा बढ़दो सिंचाई सुविधा, उन्नत तथा वर्णशंकर बीउको प्रयोग, रासायनिक मलको प्रयोगका साथै प्राविधिक ज्ञान रहेको पाइयो। अनुसन्धानका नतिजाहरु वास्तविक लाभार्थी सामु प्रभावकारी रुपमा पुर्याई अनुसन्धान तथा विकासमा सार्वजनिक नीति साभेदारीमा प्रोत्साहन गर्दे माथि उल्लेखित कारक तत्वहरुमा विचार गर्दा अन्नबालीको उत्पादन क्षमता अनुसार उत्पादन हुने देखिन्छ।

\section{INTRODUCTION}

Agriculture plays a crucial role in Nepalese economy as about $60.4 \%$ of population is engaged in agriculture for their livelihood (MoAD 2015). Besides generating employment, agriculture supports national economy by contributing 33\% in Gross Domestic Production (GDP). Nepalese agriculture, though diversified, is mostly dominated by three major cereal crops viz. rice, wheat and maize which jointly account $30.92 \%$ of Agricultural GDP of the country (MoAD 2015). These crops are vital for food security of the country. The country's selfsufficiency in food grain production has not been achieved as its growth could not keep pace with increasing demand for food. Nepal ranks $72^{\text {nd }}$ position with Global Hunger Index (GHI) of 22.0 among the world countries (IFPRI 2017).

Over the decades, Government of Nepal has introduced many policies and periodic plans to enhance productivity, profitability and commercialization of the agriculture sector. Among them, Agricultural Perspective Plan (APP) from 1995 to 2014 was the important one, expected to enhance the livelihood of Nepalese farmers substantially, if implemented appropriately. APP had aimed to accelerate the agriculture growth rate and commercialization through increased factor productivity (APP 1995). Many policies supportive 
to APP, like National Agricultural Policy (2004), Agribusiness Promotion Policy (2006), National Seed Policy (2000), National Fertilizer Policy (2002) and Irrigation Policy (2003) have been formulated after the APP was launched. Despite all these efforts, the extent of productivity growth and commercialization is low and hence 32 out of 75 districts are still food deficit in Nepal (MoAD/FAO/WFP 2015). The major challenges of Nepalese agriculture and food security at present are (1) increasing use of agriculture land for non-agricultural purposes (2) increasing out-migration of economically active population (3) negative effect of climate change (4) inadequate use of quality fertilizer (5) limited use of improved technologies and (6) small and fragmented lands that hinder mechanization and commercialization (Shrestha 2012). There is a large yield gap in yield of cereal crops which is about $1 \mathrm{t} /$ ha between research station and farmers' field, however, minimization of the yield gaps by country's Research and Development sector might improve the food security in the country (Amagain and Timsina 2005). After the APP (1995-2014), Government of Nepal has brought another plan known as Agriculture Development Strategy (ADS; 2015-2035) to address food and nutritional security through development of private and cooperative sector as one of the strategic component focusing on public private partnership (PPP) approach in several areas (MOAD 2014). Gairhe et al (2016) also highlighted the importance of PPP approach in the development of agriculture sector in Nepal.

Despite the positive aggregate national cereal balance in the recent years, domestic production has not been enough to meet the rice demand (MoAD/FAO/WFP 2015). Food import is galloping in the country as five years import data shows that the import value has inclined from NRs. 44.43 billion in 2009-10 to NRs. 127.51 billion in 2013-14. The statistics showed that the import value of cereals from India was NRs. 35.12 billion of which rice share was NRs. 23.79 billion and the maize share was 7.43 billion in 2013-14 (Kathmandu Post 2015).On the contrary, Timsina et al (2012) reported that Nepal has sufficient food to meet the national demand and tarai of Nepal had about $506247 \mathrm{t}$ of food surplus in 2011, however at the same time; the remaining two agroecological regions (Hill and Mountain) were in the food deficit condition.

Bhandari (2012) analyzed 56 years annual average total yield of major cereals from 1950/51 to 2006/07 which was $1830 \mathrm{~kg} / \mathrm{ha}$. However, above and below the average yield in different years were observed. He reported several reasons such as new technology, drought, soil fertility, farm management practices, variety of seeds, diseases and insects prevalence, and the weather were responsible for variations. Lamichhane et al (2015) highlighted maize technology intervention in western hills.

IFPRI (2011) reported the production growth in maize in the year 2001 to 2009 largely driven by yield enhancement, which shows a $2.4 \%$ growth rate, rather than by an increase in area. This increase in yields of maize is largely attributed to the use of hybrid maize seed. Similarly, as compared to the previous decade, the production growth rates of both rice and wheat declined in the period 2001-2009 (IFPRI 2011). Such analysis on the cereal production trends and dynamics in terms of area, production and productivity might be useful to understand the cause and effects. Therefore, the present work focuses on dynamics of major cereal crops over two decades and such knowledge might be useful in implementation of Agriculture Development Strategy and formulating policies for enhancing the food security situation.

\section{MATERIALS AND METHODS}

Time series data was collected from secondary sources published by government and non government agencies. Primary data was obtained through field survey with focus group discussion (FGD) from two ecological domains namely Mid hills (Syangja and Baglung Districts) and Tarai (Rupandehi, Parsa and Bara Districts). The sites were Tulsi Bhanjyang (Syangja), Kundule (Baglung), Biruwaguthi (Parsa), Fatehpur (Bara) and Mainahiya (Rupendehi). These sites were purposely selected on the basis of accessibility, where agricultural R\&D programs were carried out. FGD was conducted by using a check list to collect data related to farm production, productivity and to know the farmers perception regarding the changes in the productivity of rice, maize and wheat over these periods. The analysis was done by using 20 years data from 1995 to 2014 (APP period) on area, production and productivity of major cereals namely rice, wheat and maize. This period was further divided into two periods (1995-2004 and 2005 to 2014) for the clear understanding of the changes in the area, production and productivity of the major cereals.

\section{Percentage Change}

The change in percentage was calculated by using the following formula:

Percentage change $=($ Change value - Original value $) /$ Original value ${ }^{\times} 100$ 
Compound Growth Rate (g) Analysis

Past performance of any variable is indicated by growth of particular variables. Growth of any variable indicates its past performance. The study of growth is frequently used in economic studies to see the trend of a particular variable over a time period. It visibly indicates the performance of the variable under concern, thus can be interpreted for policy decisions. Exponential growth function was used to estimate the growth in the area, production and productivity of major cereals, which is given below:

$Y_{t}=a b^{t} u_{t}$

Where,

$Y_{t}:$ Dependent variable for which growth rate was estimated

a: Intercept

b:Coefficient of regression $(1+\mathrm{g})$

t: Years which takes values, $1,2, \ldots \ldots \ldots \ldots, \mathrm{n}$

$\mathrm{u}_{\mathrm{t}}$ : Disturbance term for the year $\mathrm{t}$

For the estimation purpose, the equation was transformed into log linear form and ordinary least square

(OLS) technique was used for estimation. The compound growth rate $(\mathrm{g})$ in percentage was then computed from the relationship:

$\mathrm{g}=\{\text { Antilog of }(\ln b)-1\}^{\times} 100$

Regression coefficient significance was tested by using the student's' test.

Annual Rate of Change

Linear time trend equation was estimated by using OLS technique to find the annual rate of change in area, production and productivity of major cereals.

Coefficient of Variation

To find out the variation in any time series data, simple analytical technique like coefficient of variation is useful (Gairhe 2011, Gupta and Sharma 2010, Ramasamy et al 2005). It is estimated as follows:

$\mathrm{CV}=(\mathrm{SD} / \text { Mean })^{\times} 100$

Where, $\mathrm{SD}=$ Standard Deviation

Instability Index

To study the fluctuation or instability in any time series data, a simple analytical technique instability index is very much useful. It is estimated as follows:

i. Parameter of a log-linear trend line is estimated for the variable (Yt) to which instability is to be estimated

ii. If the parameter that is estimated is statistically significant, then the instability index (IIN) is defined as

$\mathrm{IIN}=\mathrm{CV}^{\times}\left(1-\mathrm{r}^{2}\right)^{0.5}$

Where, $\mathrm{CV}=$ Coefficient of Variation

$\mathrm{r}^{2}=$ Coefficient of Determination

$\mathrm{CV}=(\mathrm{SD} / \text { Mean })^{\times} 100$

Where, $\mathrm{SD}=$ Standard Deviation

iii. If the estimated parameter is not significant in the regression equation, then the $\mathrm{CV}$ itself is the instability index.

\section{RESULTS}

Trend of Major Cereals in Nepal

The trend of rice, maize and wheat area in Nepal from 1995 to 2014 has been shown in Figure 1. The trend line depicts that the area under rice was slightly decreasing, whereas the area under maize and wheat were increasing. The increment was higher in wheat area as compared to maize area in the study period. The area of rice, maize and wheat were $1496790,791700,653500$ ha in 1995 , and were $1425346,882395,762373$ ha in 2014 , respectively. 


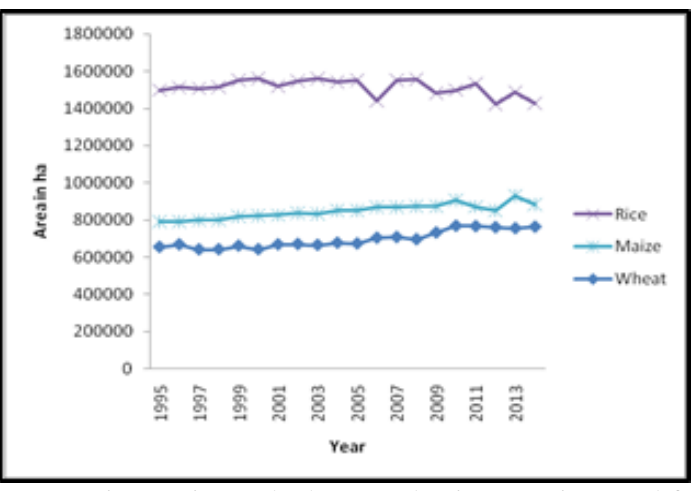

Figure 1. Rice, maize and wheat production area in Nepal from 1995 to 2014

The trend of rice, maize and wheat production in Nepal from 1995 to 2014 is shown in Figure 2 depicting that the production of rice, maize and wheat were increasing during the study periods. The production of rice, maize and wheat were $3578830,1331060,1012930 \mathrm{mt}$ in 1995 , and were $4788612,2145291,1975625 \mathrm{mt}$ in 2014, respectively. The rice, maize and wheat productivity from 1995 to 2014 in Nepal has been given in Figure 3 depicting that the productivity of rice, maize and wheat were increasing. The productivity of rice, maize and wheat were 2391, 1681, $1550 \mathrm{~kg} / \mathrm{ha}$ in 1995 and were 3360, 2431, $2591 \mathrm{~kg} / \mathrm{ha}$ in 2014 , respectively.

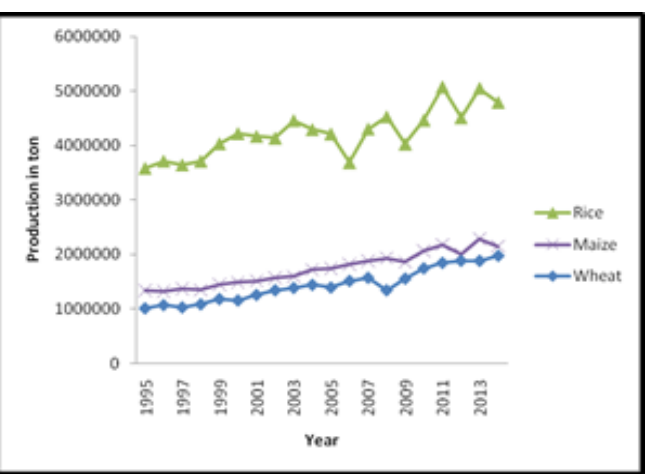

Figure 2. Rice, maize and wheat production in Nepal from 1995 to 2014 .

Average and Percentage Change in Major Cereals in Nepal

The average area, production and productivity of major cereals in Nepal from 1995 to 2014 has been shown in Table 1 segregated into three different periods, from 1995-2004 (first), 2005-2014 (second) and 1995-2014 (overall). The average area, production and yield of maize and wheat were higher in second term, and overall period as compared to first period. Rice average area was higher in first period than second and overall period, however production and yield were higher in second period and overall period as compared to first period. The area coverage under rice cultivation in Nepal still depends on monsoon rain. The total area of irrigation merely increased from 1134000 ha to 1180330 ha between 1995 and 2004 and reached up-to 1368900 ha in 2014 (FAOSTAT, 2017). The production and productivity of all the major cereals had shown increasing trend.

Table 1. Average of area, production and productivity of major cereals in Nepal

\begin{tabular}{lllllllllrr}
\hline Year & $\mathbf{1 9 9 5}$ to 2004 & \multicolumn{3}{c}{$\mathbf{2 0 0 5}$ to 2014 } & \multicolumn{3}{c}{$\mathbf{1 9 9 5}$ to 2014 } \\
\hline Crops & Area (ha) & Prod (t) & Yield (t/ha) & Area (ha) & Prod (t) & $\begin{array}{l}\text { Yield } \\
\text { (t/ha) }\end{array}$ & Area (ha) & Prod (t) & $\begin{array}{r}\text { Yield } \\
\text { (t/ha) }\end{array}$ \\
\hline Rice & 1530241 & 3992941 & 2.61 & 1493630 & 4460957 & 2.99 & 1511935 & 4226949 & 2.80 \\
\hline Maize & 817665 & 1467676 & 1.79 & 878103 & 1989330 & 2.26 & 847884 & 1728503 & 2.03 \\
\hline Wheat & 657901 & 1197496 & 1.82 & 731677 & 1671468 & 2.28 & 694789 & 1434482 & 2.05 \\
\hline
\end{tabular}

Source: MoAD 2015

Percentage change in average area, production and yield of major cereals from 1995-2004 to 2005-2014 is presented in Table 2. The result witnessed positive change and percentage increase in area, production and yield of rice, maize and wheat except rice area. The rice area was decreased by $2.39 \%$, but production and yield were increased by 11.72 and $14.64 \%$ respectively. Maize area, production and yield were increased by 7.39, 35.54 and $26.28 \%$, respectively. Similarly the wheat area, production and productivity were also showed increment by $11.21,39.58$ and 25.27 percent respectively.

Table 2. Percentage change in average area, production and productivity of major cereals in Nepal

\begin{tabular}{lllllll}
\hline Year & \multicolumn{2}{l}{ Change from 1995-2004 to 2005-2014 } & \multicolumn{3}{c}{ Percentage change from } & 1995-2004 to 2005-2014 \\
\hline Crop & Area & Prod & Yield & Area & Prod & Yield \\
\hline Rice & -36611 & 468016 & 0.38 & -2.39 & 11.72 & 14.64 \\
\hline Maize & 60438 & 521654 & 0.47 & 7.39 & 35.54 & 26.28 \\
\hline Wheat & 73776 & 473972 & 0.46 & 11.21 & 39.58 & 25.27 \\
\hline Source:
\end{tabular}


Growth Rates of Major Cereals in Nepal

Compound growth rate of major cereals is shown in Table 3. In maize and wheat, the area, production and productivity were increasing significantly however in rice; only production and productivity increased over the period of two decades. The productivity of rice, maize and wheat were increasing at the rate of $1.65,2.30$, and $2.52 \%$ per annum, respectively. The area of rice was not significant and maize and wheat areas were growing 0.69 and $1.02 \%$ per annum, respectively.

Table 3. Compound growth rate of area, production and productivity of major cereals in Nepal

\begin{tabular}{|c|c|c|c|c|c|c|c|c|c|}
\hline Year & \multicolumn{3}{|c|}{1995 to 2004} & \multicolumn{3}{|c|}{2005 to 2014} & \multicolumn{3}{|c|}{1995 to 2014} \\
\hline Crop & Area & Prod & Yield & Area & Prod & Yield & Area & Prod & Yield \\
\hline Rice & $0.38 *$ & $2.41 * *$ & $2.03 * *$ & -0.60 & $2.48 *$ & $3.11 * *$ & -0.21 & $1.43 * *$ & $1.65 * *$ \\
\hline Maize & $0.80 * *$ & $2.87 * *$ & $2.06 * *$ & 0.41 & $2.63 * *$ & $2.21 * *$ & $0.69 * *$ & $3.00 * *$ & $2.30 * *$ \\
\hline Wheat & 0.36 & $4.17 * *$ & $3.79 * *$ & $1.43 * *$ & $4.10 * *$ & $2.64 * *$ & $1.02 * *$ & $3.57 * *$ & $2.52 * *$ \\
\hline
\end{tabular}

Note: $* *$ significance at 1 percent level and $*$ significance at 5 percent level

Source: MoAD 2015

The annual rate of change in area, production and productivity of major cereals is shown in Table 4 . In the two decades, the rice yield increased by $47 \mathrm{~kg} / \mathrm{ha}$ whereas maize yield increased by $46 \mathrm{~kg} / \mathrm{ha}$ while wheat yield increased by $50 \mathrm{~kg} / \mathrm{ha}$ each year.

Table 4. Annual rate of change in area, production and productivity of major cereals in Nepal (Area in ha, Production in ton, and yield in $\mathrm{kg} / \mathrm{ha}$ )

\begin{tabular}{llllllllll}
\hline Year & $\mathbf{1 9 9 5}$ to 2004 & \multicolumn{9}{c}{$\mathbf{2 0 0 5}$ to 2014 } & \multicolumn{3}{c}{$\mathbf{1 9 9 5}$ to 2014 } \\
\hline Crop & Area & Prod & Yield & Area & Prod & Yield & Area & Prod & Yield \\
\hline Rice & 5763 & 94690 & 52 & -9009 & 108399 & 92 & -3155 & 60384 & 47 \\
\hline Maize & 6484 & 41939 & 37 & 3681 & 51523 & 49 & 5805 & 50817 & 46 \\
\hline Wheat & 2350 & 49276 & 68 & 10242 & 67009 & 60 & 7109 & 50063 & 50 \\
\hline Source: MoAD 2015 & & & & & & &
\end{tabular}

Variability of Major Cereals in Nepal

The coefficient of variation in area, production and productivity of major cereals in Nepal is shown in Table 5. In overall period the highest variation in yield was observed in wheat followed by maize and rice.

Table 5. Coefficient of variation of area, production and productivity of major cereals in Nepal

\begin{tabular}{lllllllllll}
\hline Year & $\mathbf{1 9 9 5}$ to 2004 & \multicolumn{9}{c}{$\mathbf{2 0 0 5}$ to $\mathbf{2 0 1 4}$} \\
Crop & Area & Prod & Yield & Area & Prod & Yield & Area & Prod & Yield \\
\hline Rice & 1.54 & 7.73 & 6.48 & 3.50 & 9.80 & 10.14 & 2.89 & 10.40 & 11.04 \\
\hline Maize & 2.45 & 8.97 & 6.53 & 2.71 & 8.87 & 7.31 & 4.44 & 17.79 & 13.76 \\
\hline Wheat & 2.01 & 12.85 & 11.43 & 4.79 & 13.37 & 9.29 & 6.59 & 21.37 & 15.23
\end{tabular}

Source: MoAD 2015

The instability index of area, production and productivity of major cereals in Nepal is depicted in Table 6 . Instability index was found higher in rice and wheat than that of maize yield.

Table 6. Instability index of area, production and productivity of major cereals in Nepal

\begin{tabular}{|c|c|c|c|c|c|c|c|c|c|}
\hline Year & \multicolumn{3}{|c|}{1995 to 2004} & \multicolumn{3}{|c|}{2005 to 2014} & \multicolumn{3}{|c|}{1995 to 2014} \\
\hline Crop & Area & Prod & Yield & Area & Prod & Yield & Area & Prod & Yield \\
\hline Rice & 1.03 & 2.86 & 2.27 & 3.00 & 6.52 & 4.14 & 2.61 & 6.05 & 4.84 \\
\hline Maize & 0.47 & 2.19 & 1.88 & 2.40 & 4.04 & 3.11 & 1.79 & 3.27 & 2.57 \\
\hline Wheat & 1.70 & 2.97 & 1.48 & 2.23 & 5.98 & 5.01 & 2.57 & 5.01 & 4.52 \\
\hline
\end{tabular}

Source: MoAD 2015

Focus Group Discussion (FGD) was carried out by using a check list to collect the information related to farm production and productivity. Percentage changes in productivity of major cereals from 1995 to 2015 in five districts are shown in Table 7. The result revealed that the highest percentage increment in rice and wheat were observed in Rupandehi and least in Baglung districts. In case of maize, highest increment was observed in Bara district i.e. $650 \%$ but in the study sites of Rupandehi; farmers are not cultivating maize since many years. It can be concluded from FGD that the productivity growth was much higher in the study area than that was found in national average data published by government sources. This difference might be resulted from selection bias of survey sites where production facilities were probably rich as compared to general farming condition of other areas. However, the time series data have been questioned several times for their reliability in formal and informal occasions. The use of conventional method of data collection has been criticized and modern GIS tool has been suggested to the government agencies. 
Table 7. Percentage increase in productivity of major cereals from 1995 to 2015 in five districts

\begin{tabular}{rlllll}
\hline S. No. & Ecological domain & District & Rice & Maize & Wheat \\
\hline 1 & Mid hill & Baglung & 60.00 & 222.6 & 68.00 \\
\hline 2 & Mid hill & Syanga & 100.00 & 100.0 & 100.00 \\
\hline 3 & Tarai & Rupendehi & 275.00 & $*$ & 230.00 \\
\hline 4 & Tarai & Parsa & 166.67 & 100.0 & 118.18 \\
\hline 5 & Tarai & Bara & 220.00 & 650.0 & 200.00 \\
\hline Source: $F G D 2015$ & $*$ Not cultivated in the survey site & & &
\end{tabular}

\section{DISCUSSION}

It is likely that the increase in productivity besides the adoption of improved varieties and hybrids were due to the increase use of chemical fertilizer and technical knowledge of farmers. The data obtained from the Farmers Group Discussion (FGD) was suggestive that there was substantial increase in major cereal productivity in mid hills and tarai plains during last two decades mainly due to the use of improved varieties such as Loktrantra, Sukhadhan, Sabitri, Hardinath 1, Ram Dhan, Radha 4, Khumal 10, and Khumal 13 and hybrids Gorakhnath, US 312, DY 18, DY 28, Arize 6444 (Appendix 1.5). The highest increase in productivity (275\%) in rice was reported in Rupandehi (Table 7) due to the use of hybrids. Similarly, increase in maize productivity reported by FGD was resulted from the adoption of improved varieties such as Manakamana 1, Manakaman 3, Manakamana 5, Rampur Composite, Poshilo Makai, and hybrids (DKC 9081, Pioneer 3522, 10V10). The highest increase in maize productivity $(650 \%)$ was possible in Bara due to dominance of hybrid maize. Increase in wheat productivity was by the adoption of modern varieties (Vijaya, Gautam, Vrikuti, Aaditya, and WK 1204). The highest increase in wheat productivity $(230 \%)$ in Rupandehi was responded due to the use of improved varieties developed by National Wheat Research Program (NWRP) located in the same district (Appendix 1.5). The productivity increase in maize, wheat and rice were coincided well with the varietal release and registration by Nepal Agricultural Research Council (Appendix 1.5).

MoAC (2010) reported that $83 \%$ area was covered by modern varieties of rice in the hills, whereas it was $89 \%$ in tarai plains. Different studies in different districts indicate variation in coverage of modern varieties of rice which ranges from $50 \%$ to $99 \%$ in hilly districts and from $88 \%$ to $100 \%$ in different tarai districts (SARPOD 2011, SARPOD 2013, SARPOD 2014, Shrestha et al 2012, Timsina et al 2012). Similarly, MoAC (2010) reported that $94 \%$ area was covered by modern varieties of wheat in the hills, whereas it was $100 \%$ in the tarai plains. Other studies indicated similar variation in coverage of modern varieties of wheat which ranges from $65 \%$ to $95 \%$ in hilly districts and from $94 \%$ to $100 \%$ in tarai (Shrestha et al 2012, Timsina et al 2016a, Timsina et al 2012). Moreover, MoAC (2010) reported that $87 \%$ area was covered by modern varieties of maize in the hills, whereas it was $99 \%$ in tarai plains. Shrestha et al (2012) and Timsina et al (2016b) reported that modern varieties of maize covered 60 to $90 \%$ in hilly districts and $80 \%$ to $100 \%$ in tarai districts of Nepal (Appendix 1.4).

As the production and productivity of all the major cereals have shown increasing trends but the increase in rice, maize and wheat cultivated area was not significant. The maize and wheat areas were growing only 0.69 and $1.02 \%$ per annum, respectively. The other factors contributed to increase in the productivity were the increase in use of chemical fertilizer and irrigation. The FAO statistics showed that during the study period the consumption of chemical fertilizer has increased from 111524 ton in 2003 to 273238 ton in 2014 (FAOSTAT, 2018) and Bista et al (2016) also reported that there has been increase in the use of chemical fertilizer consumption over the years. Similarly, the total area under irrigation has increased from 1134000 ha in 1995 and to 1368900 ha in 2014 (FAOSTAT, 2017).

Present study showed that the crop productivity can be resulted by composite function of variety, technology, fertilizer, and irrigation facilities, in general. Since there is no fertilizer plant in the country at present, farmers suffer from irregular supply of imported fertilizers. In this direction, fertilizer plants should be built in the country for assurance of regular supply of fertilizer. 


\section{CONCLUSION}

The area, production and productivity of major cereals have an increasing trend over the last two decades in the country. Increased irrigation facilities, use of improved and hybrid seeds and increased use of chemical fertilizer have contributed to productivity improvement in cereal crops. Better technical knowhow among the farmers has also crucially helped to rise in the productivity. Total crop production could be increased either by increase in the area or in the productivity. Since the scope of crop area increase is limited, the focus should be given to further productivity enhancement by input supply such as fertilizer, irrigation and quality seed, pest control, minimum support price, buffer stock, trade and distribution to promote the cereal cultivation and assuring market.

\section{ACKNOWLEDGEMENT}

This project was fully supported by International Food Policy Research Institute (IFPRI) in collaboration with Nepal Agricultural Research Council (NARC).

\section{REFERENCES}

ABPP. 2006. Agri-Business Promotion Policy, Ministry of Agriculture and Cooperatives (MoAC), Government of Nepal, Singhadurbar, Kathmandu, Nepal.

ADS. 2015. Agricultural Development Strategy (2015-35), Ministry of Agricultural Development, Singhadurbar, Kathmandu, Nepal.

Amgain LP and J Timsina. 2005. Major Agronomical Research Works at the Institute of Agriculture and Animal Sciences, Rampur, Chitwan, Nepal: A Review. Journal of Institute and Animal Science 26:1-20.

APP. 1995. Agriculture Perspective Plan (1995-2014), Ministry of Agriculture, Singhdurbar, Kathmandu, Nepal.

Bhandari G. 2012. Study on Agricultural Production in Nepal: a case Study in far Western Development Region. International Journal of Civil and Environmental Engineering. 12 (6): 60-70

Bista DR, S Dhungel and S Adhikari. 2016. Status of fertilizer and seed subsidy in Nepal: Review and Recommendation. The Journal of Agriculture and Environment 17:1-10.

FAOSTAT. 2017. Inputs: Land use. Accessed from http://www.fao.org/faostat/en/\#data/RL

FAOSTAT. 2018. Inputs: Fertilizer by product. Accessed from http://www.fao.org/faostat/en/\#data/RFB

Gairhe S, GN Kulkarni and S Vijayachandra Reddy. 2011. Land use dynamics in Karnataka: Post economic liberalization. Res. J. of Agri. Sci., 2(4):921-923. http://doi.org/10.5281/zenodo.1175200

Gairhe S. 2011. Land use dynamics in Karnataka: An economic analysis. M.Sc. thesis submitted to department of agricultural economics, collage of agriculture, University of Agricultural Sciences, Dharwad, Karnataka.

Gairhe S, KP Timsina, YN Ghimire, DB Thapa Magar and SL Shrestha. 2016. Tomato hybrid seed production: Initiation of Public Private Partnership Approach in Agriculture. Nepalese Horticulture Journal 11: 2128. http://doi.org/10.5281/zenodo.1175187

Gupta S and RK Sharma. 2010. Dynamics of land utilization, land degradation and factors determining land degradation in Himachal Pradesh. Indian J. Agri. Econ. 65 (2): 245-260.

IFPRI. 2011. A Review of Input and Output Policies for Cereals Production in Nepal. Discussion Paper 01114

IFPRI. 2017. Global Hunger Index, International Food Policy Research Institute. 2017.

IP. 2003. Irrigation Policy, Ministry of Agriculture and Cooperatives (MoAC), Government of Nepal, Singhadurbar, Kathmandu, Nepal.

Kathmandu Post. 2015. Agro Product top import list. Accessed from http://kathmandupost.ekantipur.com/printedition/news/2015-11-27/agro-products-top-import-list.html

Lamichhane J, KP Timsina, DB RanaBhat and S Adhikari. 2015. Technology adoption analysis of improved maize technology in western hills of Nepal. Journal of Maize Research and Development 1:146-152.

MoAC. 2010. Statistical Information on Nepalese Agriculture. Ministry of Agriculture and Cooperatives (MoAC), Government of Nepal, Singhadurbar, Kathmandu, Nepal.

MoAD. 2014. Food Balance Sheet of Nepal. Ministry of Agricultural Development. Kathmandu, Nepal. 2014.

MoAD. 2015. Selected Indicators of Agriculture. Government of Nepal, Ministry of Agricultural Development, Agribusiness Promotion and Statistics Division, Food Security and Environment Division, Singhadurbar, Kathmandu, Nepal.

MoAD. 2015. Statistical Information on Nepalese Agriculture, Ministry of Agricultural Development, 2015.

MoAD/FAO/WFP. 2015. Crop Situation Update: A joint assessment of 2014/15 winter crops. Published by Ministry of Agricultural Development, Food and Agriculture Organization and World Food Program, Kathmandu, Nepal.

NAP. 2004. National Agricultural Policy 2004, Ministry of Agriculture and Cooperatives (MoAC), Government of Nepal, Singhadurbar, Kathmandu, Nepal.

NFP. 2002. National Fertilizer Policy, Ministry of Agriculture and Cooperatives (MoAC), Government of Nepal, Singhadurbar, Kathmandu, Nepal.

NSP. 2000. National Seed Policy, Ministry of Agriculture and Cooperatives (MoAC), Government of Nepal, Singhadurbar, Kathmandu, Nepal.

Ramasamy C, R Balasubramanian and SD Sivakumar. 2005. Dynamics of land use pattern with special reference to fallow lands- An empirical investigation in Tamil Nadu. Indian J. Agri. Econ. 60(4):629-644. 
SARPOD. 2011. Annual Report (2010/11). Socioeconomics and Agricultural Research Policy Division, NARC, Khumaltar, Lalitpur, Nepal.

SARPOD. 2013. Annual Report (2012/13). Socioeconomics and Agricultural Research Policy Division, NARC, Khumaltar, Lalitpur, Nepal.

SARPOD. 2014. Annual Report (2013/14). Socioeconomics and Agricultural Research Policy Division, NARC, Khumaltar, Lalitpur, Nepal.

Shrestha HK, HK Manandhar and PP Regmi. 2012. Variety Development Cost versus Variety Adoption in Major Cereals in Nepal. Nepal Journal of Science and Technology 13(1):7-15. http://dx.doi.org/10.3126/njst.v13i1.7393

Shrestha S. 2012. Status of Agriculture Mechanisation in Nepal. Agricultural Engineering Division (AED), NARC, Khumaltar, Nepal. pp 1-4. www.unapcaem.org

Timsina KP, KP Shrestha and S Pandey. 2012. Factors affecting adoption of new modern varieties of Rice in eastern Tarai of Nepal. In: the proceeding of 4th Society of Agricultural Scientist-Nepal (SAS-N) conference held at Lalitpur 4-6 April, 2012. Published by Nepal Agricultural Research Council (NARC) and Society of Agricultural Scientists (SAS-N), Nepal, pp 48-54.

Timsina KP, S Gairhe, DB Thapa Magar, YN Ghimire, D Gauchan and Y Padhyoti. 2016a. On farm research is a viable means of technology verification, dissemination and adoption: A case of Wheat research in Nepal. Agronomy Journal of Nepal 4: 9-24. http://dx.doi.org/10.3126/ajn.v4i0.15513

Timsina KP, YN Ghimire and J Lamichane. 2016b. Maize production in mid hills of Nepal: from food to feed security. Journal of Maize Research and Development 2(1): 20-29. http://dx.doi.org/10.3126/jmrd.v2i1.16212

Timsina KP. 2012. Analysis of Energy Requirements, Food Consumption Patterns and Food Security Situation in Nepal. Report submitted to the School of Environment, Resources and Development (SERD), Asian Institute of Technology (AIT), Thailand. 


\section{APPENDICES}

Appendix 1.1. Compound growth rate function for area, production, productivity of major cereals for period I (1995 to 2004)

\begin{tabular}{|l|l|r|r|r|r|r|r|}
\hline Crops & Variables & CGR & A & B & $\mathbf{R}^{2}$ & F & t \\
\hline \multirow{3}{*}{ Rice } & Area & 0.38 & 14.22 & 0.00 & 0.55 & 9.82 & 3.13 \\
\cline { 2 - 9 } & Production & 2.41 & 15.07 & 0.02 & 0.86 & 50.64 & 7.12 \\
\cline { 2 - 9 } & Productivity & 2.03 & 7.75 & 0.02 & 0.88 & 57.24 & 7.12 \\
\hline \multirow{3}{*}{ Maize } & Area & 0.80 & 13.57 & 0.01 & 0.96 & 204.58 & 14.30 \\
\cline { 2 - 9 } & Production & 2.87 & 14.04 & 0.03 & 0.94 & 125.80 & 11.22 \\
\cline { 2 - 9 } & Productivity & 2.06 & 7.38 & 0.02 & 0.92 & 88.87 & 9.43 \\
\hline \multirow{3}{*}{ Wheat } & Area & 0.36 & 13.38 & 0.00 & 0.29 & 3.20 & 1.79 \\
\cline { 2 - 8 } & Production & 4.17 & 13.76 & 0.04 & 0.95 & 141.92 & 11.91 \\
\cline { 2 - 8 } & Productivity & 3.79 & 7.29 & 0.04 & 0.98 & 469.65 & 21.67 \\
\hline
\end{tabular}

Appendix 1.2. Compound growth rate function for area, production, productivity of major cereals for period II (2005 to 2014)

\begin{tabular}{|l|l|r|r|r|r|r|r|}
\hline Crops & Variables & CGR & A & B & $\mathbf{R}^{2}$ & F & t \\
\hline \multirow{4}{*}{ Rice } & Area & -0.60 & 14.25 & -0.01 & 0.27 & 2.95 & -1.72 \\
\cline { 2 - 9 } & Production & 2.48 & 15.17 & 0.02 & 0.56 & 10.07 & 3.17 \\
\cline { 2 - 9 } & Productivity & 3.11 & 7.83 & 0.03 & 0.83 & 40.03 & 6.33 \\
\hline \multirow{3}{*}{ Maize } & Area & 0.41 & 13.66 & 0.00 & 0.22 & 2.23 & 1.49 \\
\cline { 2 - 9 } & Production & 2.63 & 14.36 & 0.03 & 0.79 & 30.53 & 5.53 \\
\cline { 2 - 9 } & Productivity & 2.21 & 7.60 & 0.02 & 0.82 & 36.27 & 6.02 \\
\hline \multirow{3}{*}{ Wheat } & Area & 1.43 & 13.42 & 0.01 & 0.78 & 28.89 & 5.37 \\
\cline { 2 - 9 } & Production & 4.10 & 14.10 & 0.04 & 0.80 & 32.02 & 5.66 \\
\cline { 2 - 9 } & Productivity & 2.64 & 7.58 & 0.03 & 0.71 & 19.46 & 4.41 \\
\hline
\end{tabular}

Appendix 1.3. Compound growth rate function for area, production, productivity of major cereals for overall period (1995 to 2014)

\begin{tabular}{|l|l|r|r|r|r|r|r|}
\hline Crops & Variables & CGR & A & B & $\mathbf{R}^{2}$ & F & t \\
\hline \multirow{4}{*}{ Rice } & Area & -0.21 & 14.25 & 0.00 & 0.19 & 4.11 & -2.03 \\
\cline { 2 - 9 } & Production & 1.43 & 15.10 & 0.01 & 0.66 & 35.13 & 5.93 \\
\cline { 2 - 9 } & Productivity & 1.65 & 7.76 & 0.02 & 0.81 & 75.60 & 8.70 \\
\hline \multirow{3}{*}{ Maize } & Area & 0.69 & 13.58 & 0.01 & 0.84 & 93.57 & 9.67 \\
\cline { 2 - 9 } & Production & 3.00 & 14.04 & 0.03 & 0.97 & 515.67 & 22.71 \\
\cline { 2 - 9 } & Productivity & 2.30 & 7.37 & 0.02 & 0.97 & 498.16 & 22.32 \\
\hline \multirow{3}{*}{ Wheat } & Area & 1.02 & 13.34 & 0.01 & 0.85 & 100.79 & 10.04 \\
\cline { 2 - 8 } & Production & 3.57 & 13.79 & 0.04 & 0.95 & 309.54 & 17.59 \\
\cline { 2 - 8 } & Productivity & 2.52 & 7.35 & 0.02 & 0.91 & 186.40 & 13.65 \\
\hline
\end{tabular}

Appendix 1.4. Area covered by modern varieties of Rice, Wheat and Maize

\begin{tabular}{|c|c|c|}
\hline Crops & Hills & Tarai \\
\hline Rice & $\begin{array}{l}\text { Overall } 83 \% \text { (MoAC 2010) } \\
50 \% \text { in Doti, } 95 \% \text { in Kavre (Shrestha et al 2012) } \\
95.2 \% \text { in Bhaktapur, } 73.5 \% \text { in Dhading, } 33.2 \% \text { in } \\
\text { Dhankuta, } 22.4 \% \text { in Jumla, } 97.5 \% \text { Kavre, } 99 \% \text { in } \\
\text { Nuwakot, } 7.2 \% \text { Sangkhuwasabha, } 94.5 \% \text { in Sindhuli } \\
\text { (SARPOD 2011) } \\
\text { 85.7\% in Palpa and 92.6\% in Syanja (SARPOD 2013) } \\
61.4 \% \text { in Doti (SARPOD 2014) }\end{array}$ & $\begin{array}{l}89 \% \text { (MoAC 2010) } \\
95 \% \text { in Rupandehi, } 100 \% \text { in Bara (Shrestha et al } \\
2012 \text { ) } \\
97.7 \% \text { in Bara, } 96.3 \% \text { in Jhapa, } 89.6 \% \text { in } \\
\text { Mahottari, } 94.2 \% \text { in Morang, } 96.5 \text { in Sarlahi } \\
\text { (SARPOD 2013) } \\
88.5 \% \text { in Sunsari and Mahottari (Timsina et al } \\
2012 \text { ) } \\
94.2 \% \text { in Kailali, } 92.5 \% \text { in Kanchanpur (SARPOD } \\
2014 \text { ) }\end{array}$ \\
\hline Wheat & $\begin{array}{l}94 \% \text { (MoAC 2010) } \\
65 \% \text { in Doti, } 95 \% \text { in Dhankuta (Shrestha et al 2012) }\end{array}$ & $\begin{array}{l}\text { 100\% (MoAC 2010) } \\
98 \% \text { in Sunsari, 100\% in Bara, Rupandehi, Banke } \\
\text { and Kailali (Shrestha et al 2012) } \\
94 \% \text { in Sunsari, Rupandehi and Banke (Timsina et } \\
\text { al 2016a) }\end{array}$ \\
\hline Maize & $\begin{array}{l}87 \% \text { (MoAC 2010) } \\
60 \% \text { in Doti, 95\% in Kavre (Shrestha et al 2012) } \\
60 \% \text { in Baglung, 65\% in Palpa (Lamichhane et al 2015) } \\
\text { More than } 70 \% \text { in Kavre and Lamjung (Timsina et al } \\
2016 \text { b) }\end{array}$ & $\begin{array}{l}\text { 99\% (MoAC 2010) } \\
85 \% \text { in Rupandehi, 100\% in Sunsari, Bara and } \\
\text { Kailai (Shrestha et al 2012) }\end{array}$ \\
\hline
\end{tabular}


Appendix 1.5. List of rice, maize and wheat varieties released and registered during the study period (1995-2014) with their productivity

\begin{tabular}{|c|c|c|c|c|}
\hline Rice Varieties & Year & $\begin{array}{l}\text { Released/ } \\
\text { registered }\end{array}$ & $\begin{array}{l}\text { Productivity } \\
\text { (ton/ha) }\end{array}$ & Recommended domain \\
\hline Radha 4 & 1195 & Released & 3.20 & Tarai of Mid Far western and Far Western Region \\
\hline Radha 11 & 1995 & Released & 4.00 & Mid tarai \\
\hline Radha 12 & 1995 & Released & 4.60 & Eastern tarai \\
\hline Macchapuchre 3 & 1996 & Released & 5.00 & Mid to high hills from 1400 to 2000 masl \\
\hline Khumal 6 & 1999 & Released & 7.80 & Kathmandu valley and similar conditions of mid hills \\
\hline Rampur Masuli & 1999 & Released & 5.70 & Tarai, inner tarai and lowland up to 900 masl of mid hills \\
\hline Chandannath 1 & 2002 & Released & 5.05 & Jumla and similar climatic conditions \\
\hline Chandannath 3 & 2002 & Released & 5.30 & Jumla and similar climatic conditions \\
\hline Manjushri 2 & 2002 & Released & 10.08 & Kathmandu valley \\
\hline Khumal 11 & 2002 & Released & 8.50 & Kathmandu valley \\
\hline Loktantra & 2006 & Released & 3.60 & Tarai, inner tarai, lower hills and river basin of mid hills \\
\hline Mithila & 2006 & Released & $3.5-4.5$ & Tarai, inner tarai and lowland mid hills \\
\hline Ram & 2006 & Released & $4.0-7.2$ & Tarai and inner tarai \\
\hline Barkhe 3004 & 2006 & Released & 3.80 & Tarai and inner tarai \\
\hline Pokhreli Jethobudo & 2006 & Released & 2.60 & Pokhara valley from 600 to 900 masl \\
\hline Khumal 8 & 2007 & Released & 7.70 & Mid hills and lower hills \\
\hline Sunaulo Sugandha & 2008 & Released & 3.80 & Tarai and inner tarai \\
\hline Ghaiya 1 & 2010 & Released & $2.5-3.5$ & Unirrigated upland, tarai plain and valleys in mid hills \\
\hline Lalka Basmati & 2010 & Released & $2.5-3.5$ & Central and eastern tarai \\
\hline Hardinath 2 & 2010 & Released & $3.1-4.2$ & Tarai and inner tarai \\
\hline Tarahara 1 & 2010 & Released & 4.20 & Central and eastern tarai \\
\hline DY 18 & 2010 & Registered & 9.17 & Tarai and inner tarai \\
\hline DY 28 & 2010 & Registered & 8.86 & Tarai and inner tarai \\
\hline DY 69 & 2010 & Registered & 9.52 & Tarai and inner tarai \\
\hline Khumal 10 & 2011 & Released & 4.78 & Kathmandu valley and similar conditions of mid hills \\
\hline Khumal 13 & 2011 & Released & 4.17 & Kathmandu valley and similar conditions of mid hills \\
\hline Sukha Dhan 1 & 2011 & Released & $3.2-4.2$ & $\begin{array}{l}\text { Eastern and Western tarai, inner tarai and river basins upto } 500 \\
\text { masl in mid hills }\end{array}$ \\
\hline Sukha Dhan 2 & 2011 & Released & $2.3-3.5$ & $\begin{array}{l}\text { Eastern and Western tarai, inner tarai and river basins upto } 500 \\
\text { masl in mid hills }\end{array}$ \\
\hline Sukha Dhan 3 & 2011 & Released & $2.5-3.6$ & $\begin{array}{l}\text { Eastern and Western tarai, inner tarai and river basins upto } 500 \\
\text { masl in mid hills }\end{array}$ \\
\hline Barkhe 2014 & 2011 & Released & 3.80 & Tarai \\
\hline Swarna Sub1 & 2011 & Released & $4.0-5.0$ & $\begin{array}{l}\text { Tarai, inner tarai and irrigated area and lowland upto } 500 \text { masl } \\
\text { of mid hills }\end{array}$ \\
\hline Barkhe 1027 & 2011 & Registered & 3.30 & $\begin{array}{l}\text { Un-irrigated tarai, semi irrigated and un-irrigated area upto } 1000 \\
\text { masl of mid hills }\end{array}$ \\
\hline Samba masuli sub1 & 2011 & Released & $3.5-4.0$ & $\begin{array}{l}\text { Tarai, inner tarai and irrigated area and lowland upto } 500 \text { masl } \\
\text { of mid hills }\end{array}$ \\
\hline Tara F1 & 2011 & Registered & 5.10 & Tarai and inner tarai \\
\hline SurajF1 & 2011 & Registered & 5.77 & Tarai and inner tarai \\
\hline Prithivi F1 & 2011 & Registered & 6.00 & Irrigated area of tarai and inner tarai \\
\hline Arise $6444 \mathrm{~F} 1$ & 2011 & Registered & 4.43 & Irrigated area of tarai and inner tarai \\
\hline PHB 71 F1 & 2011 & Registered & 5.26 & Irrigated area of tarai \\
\hline US 312 F1 & 2011 & Registered & 5.46 & Tarai and inner tarai \\
\hline Champion F1 & 2011 & Registered & 5.15 & Irrigated area of eastern to western tarai and inner tarai \\
\hline Raja F1 & 2011 & Registered & 4.94 & Irrigated area of eastern to western tarai and inner tarai \\
\hline RH 257 F1 & 2011 & Registered & 4.99 & Tarai and inner tarai \\
\hline Gorakhnath 509 F1 & 2011 & Registered & 4.82 & Tarai and inner tarai \\
\hline Loknath 505 F1 & 2011 & Registered & 4.79 & Irrigated area of tarai and inner tarai \\
\hline PAC 801 F1 & 2011 & Registered & 7.79 & Irrigated area of tarai and inner tarai \\
\hline Reshma 786 F1 & 2011 & Registered & 4.91 & Irrigated area of eastern tarai \\
\hline BaishaliF1 & 2011 & Registered & 6.35 & Irrigated area of eastern tarai \\
\hline Lekali Dhan 1 & 2014 & Released & 4.07 & High hills upto $1500-2600$ masl \\
\hline Lekali Dhan 3 & 2014 & Released & 3.90 & High hills upto $1500-2600$ masl \\
\hline Sukkha Dhan 4 & 2014 & Released & $2.7-4.0$ & $\begin{array}{l}\text { Un-irrigated land of tarai, Inner tarai and Mid hills upto } 500 \\
\text { masl }\end{array}$ \\
\hline Sukkha Dhan 5 & 2014 & Released & $3.2-4.2$ & Unirrigated land of tarai, Inner tarai and Mid hills upto 500 mas \\
\hline
\end{tabular}




\begin{tabular}{|c|c|c|c|c|}
\hline Rice Varieties & Year & $\begin{array}{l}\text { Released/ } \\
\text { registered }\end{array}$ & $\begin{array}{l}\text { Productivity } \\
\text { (ton/ha) }\end{array}$ & Recommended domain \\
\hline Sukkha Dhan 6 & 2014 & Released & $3.0-4.0$ & Unirrigated land of tarai, Inner tarai and Mid hills upto 500 masl \\
\hline Arun 1 & 1995 & Released & 4.00 & Western Tarai and Mid hills \\
\hline Ganesh 1 & 1997 & Released & 5.00 & High hills \\
\hline Manakamana 3 & 2002 & Released & 5.50 & $\begin{array}{l}\text { Mid hills of Eastern, Central and Western Development regions } \\
\text { from } 1000 \text { to } 1700 \text { masl }\end{array}$ \\
\hline $\begin{array}{l}\text { Gaurab Hybrid } \\
\text { Makai }\end{array}$ & 2003 & Released & 8.10 & Tarai and Inner Tarai \\
\hline Deuti & 2006 & Released & 5.70 & Mid hills \\
\hline Sitala & 2006 & Released & 6.08 & Hills \\
\hline Manakamana 4 & 2008 & Released & 5.30 & Eastern to western mid hills at altitude less than 1600 masl \\
\hline Posilo makai 1 & 2008 & Released & 5.30 & Eastern to western mid hills at altitude less than 1600 masl \\
\hline Manakamana 5 & 2010 & Released & 5.27 & Mid hills east of Karnali \\
\hline Manakamana 6 & 2010 & Released & 5.34 & Eastern and mid-western hills \\
\hline Bayo 9681 F1 & 2010 & Registered & $6.5-8$ & $\begin{array}{l}\text { Mid hills of central region during summer, eastern tarai during } \\
\text { winter }\end{array}$ \\
\hline RajkumarF1 & 2010 & Registered & $8.0-9.0$ & Tarai, Inner tarai, river basin and valleys upto 700 masl \\
\hline Nutan KH 101 F1 & 2010 & Registered & $6.5-8$ & Tarai, Inner tarai, river basin and valleys upto 700 masl \\
\hline Super 900 M F1 & 2010 & Registered & $8.0-12.0$ & Mid tarai- winter and summer season \\
\hline DKC $9081 \mathrm{~F} 1$ & 2011 & Registered & $10.0-12.0$ & Mid tarai for winter season \\
\hline All rounderF1 & 2011 & Registered & $7.0-10.0$ & Tarai area- winter and summer season \\
\hline DKC 7074 F1 & 2011 & Registered & $6.0-8.0$ & $\begin{array}{l}\text { Mid hills of central region - summer season , mid tarai for spring } \\
\text { season }\end{array}$ \\
\hline $30 \mathrm{P} 30 \mathrm{~F} 1$ & 2011 & Registered & $6.0-7.0$ & $\begin{array}{l}\text { Mid hills of central region for summer season, tarai for winter } \\
\text { season }\end{array}$ \\
\hline $30 \mathrm{~B} 11 \mathrm{~F} 1$ & 2011 & Registered & $8.0-9.0$ & $\begin{array}{l}\text { Mid hills of central region for summer season, tarai for winter } \\
\text { season }\end{array}$ \\
\hline Bisko $940 \mathrm{~F} 1$ & 2011 & Registered & 7.13 & Central tarai and hills \\
\hline C $1921 \mathrm{~F} 1$ & 2011 & Registered & $5.14-7.5$ & Eastern and central tarai, river basin and upland of mid hills \\
\hline CP 808 F1 & 2011 & Registered & 9.95 & Eastern and central tarai \\
\hline CP 666 F1 & 2011 & Registered & 6.97 & Eastern and central tarai \\
\hline Godawari 989 F1 & 2011 & Registered & 7.36 & Eastern and central tarai, river basin and upland of mid hills \\
\hline Early 2 F1 & 2011 & Registered & 5.69 & Eastern and central tarai, river basin and upland of mid hills \\
\hline TCS 9696 F1 & 2011 & Registered & 8.34 & Central tarai and hills \\
\hline Rampur Hybrid 2 & 2012 & Released & $3.55-7.0$ & Inner tarai and tarai east of Narayani river \\
\hline RML 4 & 2012 & Released & $2.5-3.0$ & Inner tarai and tarai east of Narayani river \\
\hline NML 2 & 2012 & Released & $2-2.5 .0$ & Inner tarai and tarai east of Narayani river \\
\hline Aditya 929 F1 & 2012 & Registered & 7.20 & Inner tarai and tarai east of Narayani river \\
\hline Pro Agro $4262 \mathrm{~F} 1$ & 2012 & Registered & 8.29 & Inner tarai and tarai east of Narayani river \\
\hline Bisko 940 New F1 & 2012 & Registered & 7.74 & Inner tarai and tarai east of Narayani river \\
\hline CP 838 F1 & 2012 & Registered & 7.11 & Inner tarai and tarai east of Narayani river \\
\hline $10 \mathrm{~V} 10 \mathrm{~F} 1$ & 2012 & Registered & 7.46 & Inner tarai and tarai east of Narayani river \\
\hline DMH 7314 F1 & 2012 & Registered & 6.66 & Inner tarai and tarai east of Narayani river \\
\hline DMH 849 F1 & 2012 & Registered & 6.85 & Inner tarai and tarai east of Narayani river \\
\hline MM 1107 F1 & 2012 & Registered & 9.00 & Inner tarai and tarai east of Narayani river \\
\hline Decalb Double F1 & 2012 & Registered & 6.79 & Inner tarai and tarai east of Narayani river \\
\hline Big boss F1 & 2012 & Registered & 8.39 & Inner tarai and tarai east of Narayani river \\
\hline NMH 731 F1 & 2012 & Registered & 7.92 & Inner tarai and tarai east of Narayani river \\
\hline Pioneer 3522 F1 & 2012 & Registered & 8.65 & Inner tarai and tarai east of Narayani river \\
\hline Pioneer $3785 \mathrm{~F} 1$ & 2012 & Registered & 8.45 & Inner tarai and tarai east of Narayani river \\
\hline $9220 \mathrm{~F} 1$ & 2012 & Registered & 7.67 & Inner tarai and tarai east of Narayani river \\
\hline TX 369 F1 & 2012 & Registered & 9.00 & Inner tarai and tarai east of Narayani river \\
\hline C 1946 F1 & 2012 & Registered & 9.70 & Inner tarai and tarai east of Narayani river \\
\hline $\begin{array}{l}\text { Khumal Hybrid } \\
\text { Makai } 2\end{array}$ & 2014 & Released & $8.5-9.08$ & $\begin{array}{l}\text { Summer season in Mid Hills and winter season in tarai and } \\
\text { Inner tarai }\end{array}$ \\
\hline KYM 33 & 2014 & Released & 2.50 & $\begin{array}{l}\text { Summer season in Mid Hills and winter season in tarai and } \\
\text { Inner tarai }\end{array}$ \\
\hline KYM 35 & 2014 & Released & 1.50 & $\begin{array}{l}\text { Summer season in Mid Hills and winter season in tarai and } \\
\text { Inner tarai }\end{array}$ \\
\hline Resunga Composite & 2014 & Released & 5.20 & Hills of Central and Western Region from 700 to 1400 masl \\
\hline
\end{tabular}




\begin{tabular}{|l|r|l|l|l|}
\hline Rice Varieties & Year & $\begin{array}{l}\text { Released/ } \\
\text { registered }\end{array}$ & $\begin{array}{l}\text { Productivity } \\
\text { (ton/ha) }\end{array}$ & Recommended domain \\
\hline Gulmi 2 & 2014 & Registered & 5.40 & Gulmi and Arghakhanchi Districts from 700 to 1400 masl \\
\hline Achyut & 1997 & Released & 4.50 & Upland lower than 1000 masl \\
\hline Rohini & 1997 & Released & 4.10 & Tarai upland lower than 1000 masl \\
\hline Pasang Lamhu & 1997 & Released & 6.70 & Mid hills \\
\hline Kanti & 1997 & Released & 5.50 & Hills \\
\hline BL 1473 & 1999 & Released & 4.00 & Tarai upland lower than 1000 masl \\
\hline Gautam & 2004 & Released & 3.40 & Tarai upland upto 500 masl \\
\hline WK 1204 & 2007 & Released & 3.40 & Mid hills and high hills \\
\hline Aditya & 2010 & Released & 4.79 & Tarai upland upto 500 masl \\
\hline NL 971 & 2010 & Released & 4.53 & Tarai upland upto 500 masl \\
\hline Bijaya & 2011 & Released & 4.45 & Tarai upland upto 500 masl \\
\hline Gaura & 2012 & Released & $4.2-5.0$ & Mid hills and high hills \\
\hline Dhaulagiri & 2012 & Released & $3.6-4.9$ & Mid hills and high hills \\
\hline
\end{tabular}

